\title{
Research on Protection and Utilization of Irrigation Works Heritage in Hetao Irrigation District in Inner Mongolia
}

\author{
Deng Jun ${ }^{1,2,}$ a, Tan Xuming ${ }^{1}$, Wang Li $^{1,2}$, Li Yunpeng ${ }^{1,2}$, Liu Jiangang ${ }^{1,2}$, Zhou Bo ${ }^{1,2}$ \\ ${ }^{1}$ Institute of Water Conservancy History of China Institute of Water Resources and Hydropower Research, Beijing, 100038, China \\ ${ }^{2}$ Research Center on Flood Control, Drought Control and Disaster Mitigation of the Ministry of Water Resources, Beijing, 100038, China
}

\begin{abstract}
Hetao Irrigation District in Inner Mongolia was built in the Qin and Han Dynasties and has been fulfilling its good irrigation function. Through field investigation, data collection and visits to experts, scholars and management departments, this paper summarizes the historical evolution and composition of irrigation works heritage in Hetao Irrigation District and its historical, social and scientific values.
\end{abstract}

\section{Overview}

Hetao Irrigation District is located in Bayan Nur City in the west of Inner Mongolia Autonomous Region. The Yellow River flows through the south of this city. That is, Hetao Irrigation District is located on the Hetao Plain between Yinshan Mountains and Yellow River. Hetao area is in the arid desert area with low rainfall and had drawn water for farmland irrigation from the Yellow River for more than 2000 years. With the benefit of intake for irrigation use from the Yellow River, this area has become one of the most fertile areas in the upper reaches of the Yellow River, known as "Sole Beneficiary under the Flooding of the Yellow River" and

"Southern Frontier". Sanshenggong Water Control Project was accomplished in 1961. Since then, Hetao Irrigation District has become a single-head artesian diversion irrigation area. With the current irrigated area of 10.2 million $\mathrm{mu}$, it is one of the three super large irrigation areas in China. Hetao Irrigation District was included in the World Heritage Irrigation Structures in 2019.

Hetao Irrigation District is located on Jizi- shaped bend on the North Bank of the Inner Mongolia section of the Yellow River. It is bounded on the north by Langshan Mountain and Wula Mountain, bounded on the west by Ulanbuh desert and adjacent to suburb of Baotou City on the east. The Yellow River runs through it from west to east on the south. The whole irrigation district is about $270 \mathrm{~km}$ long from east to west and $50-70 \mathrm{~km}$ wide from south to north, with an area of about $15900 \mathrm{~km} 2$. At present, the irrigated area is 10.2 million mu. Hetao Irrigation District was formed mainly by flood impact of the Yellow River, with flat terrain and fertile land. The overall terrain inclines from southwest to northeast.

\section{Historical Evolution}

The irrigational development in Hetao area can be traced back to Qin Dynasty, and canalizing and irrigating projects were clearly documented in Han Dynasty. After the loosening of reclamation ban policy in Hetao pastoral area during the reign of Emperor Daoguang in the Qing Dynasty, the Yellow River diversion irrigation projects have developed rapidly ${ }^{[1]}$. By the third year of the reign of Emperor Xuantong (1911), with eight main canals of Yongji, Gangji, Fengji, Shahe, Yihe, Tongji, Changji and Tabu rivers as the core, more than 40 main canals diverting water from the Yellow River were built in Hetao Plain, with the irrigated area of more than 1 million mu, and Hetao Irrigation District began to take shape ${ }^{[2]}$. During the Republic of China era, Hetao Irrigation District continued to develop. Based on eight main canals, ten main canals were built, including Tabu Canal (Tabu River), Changji Canal (Changsheng Canal), Tongji Canal (Laoguo Canal), Yihe Canal (Wangtongchun Canal), Fuxing Canal (Shahe Canal), Fengji Canal (Zhonghe Canal), Yongji Canal, Huangji Canal, Yangjia River and Zaohuo Canal. The engineering system pattern of Hetao Irrigation District was basically formed, with the irrigated area of more than 4 million mu. After 1949, ten main canals were integrated and adjusted into thirteen main canals, namely (from west to east) Shenwu Main Canal, Wula River, Yangjia River, Huangji Canal, Yongji Canal, Fengji Canal, Zaohuo Canal, Shahe Canal, Yihe Canal, Tongji Canal, Changji Canal, Tabu Canal and Sanhuhe Main Canal. Sanshenggong Water Control Project was accomplished in 1961. Since then, Hetao Irrigation District has become a super large irrigation area with single-head artesian diversion irrigation and seven-stage irrigation and drainage system.

\section{Composition}

The irrigation works heritage in Hetao Irrigation District is represented by 13 historical irrigation canal systems, including irrigation and drainage engineering system before 1949, abandoned irrigation and drainage engineering facilities remains, relics and sites, and non- 
engineering heritages that witness or bear the historical and heritage value of Hetao Irrigation District, such as inscriptions, documents, Dragon King Temple and other facilities for worship of water god, building facilities. There are many traditional hydraulic measures, historical sites, and historical and cultural relics that are still in use in Hetao Irrigation District. They have witnessed the development process of Hetao Irrigation District and added unique cultural connotation to it. Table 1 shows further details.

Table 1. Composition of Irrigation Works Heritage in Hetao Irrigation District

\begin{tabular}{|c|c|}
\hline Category & Heritage feature names \\
\hline $\begin{array}{c}\text { Sanshenggong Water } \\
\text { Control Project }\end{array}$ & \\
\hline $\begin{array}{l}\text { Historical Irrigation } \\
\text { canals }\end{array}$ & $\begin{array}{c}\text { Shenwu Main Canal, Wula } \\
\text { River, Yangjia River, Huangji } \\
\text { Canal, Yongji Canal, Fengji } \\
\text { Canal, Zaohuo Canal, Shahe } \\
\text { Canal, Yihe Canal, Tongji } \\
\text { Canal, Changji Canal, Tabu } \\
\text { Canal and Sanhuhe Main } \\
\text { Canal }\end{array}$ \\
\hline Drainage ditches & $\begin{array}{l}1 \text { general main drainage ditch, } \\
12 \text { main drainage ditches, } 45 \\
\text { sub-main drainage ditches, } \\
137 \text { branch ditches and } 11,275 \\
\text { lateral drainage ditches }\end{array}$ \\
\hline $\begin{array}{c}\text { Non-engineering } \\
\text { heritages }\end{array}$ & $\begin{array}{c}\text { Inscriptions, documents, } \\
\text { Dragon King Temple }\end{array}$ \\
\hline
\end{tabular}

Hetao Irrigation District diverts water from the Yellow River via Sanshenggong Water Control Project, conveys water to the fields and lakes and tarns, general main drainage ditch, 12 main drainage ditches and all levels of drainage ditches by the general main canal, 13 main canals and all levels of channels, delivers water to Wuliangsuhai Drainage Receiver via Honggebu Lift Station, and finally discharges water back to Yellow River from the outlet section of the general main drainage ditch.

\subsection{Sanshenggong Water Control Project}

Sanshenggong Water Control Project is located on the Yellow River artery in the southeast of the former Sanshenggong Town in Dengkou County. Its barrage water-diversion works are set up across the Yellow River and composed of sluice, barrage, intake sluice of general main canal on north bank, desilting basin, intake sluice of Shenwu Main Canal, intake sluice of main canal on south bank, hydraulic drop hydropower station on general main canal and reservoir cofferdam. The Project was started in June 1959 and completed in May 1961. It is a key watercontrol project with agricultural and animal husbandry irrigation as the main part and with the benefits of local navigation and power generation.

\subsection{Irrigation canals}

There is one general main canal in the Hetao Irrigation District, with a total length of $228.9 \mathrm{~km}$. The general main canal has 13 main canals with a total length of $755 \mathrm{~km} ; 48$ sub-main canals with a total length of $1,062 \mathrm{~km}$; and 85,861 branch canals, lateral canals, field canals and sublateral canals with a total length of $47,324 \mathrm{~km}$. The general main canal is provided with 4 diversion sluices. The first and second diversion sluices are for water diversion of 2 main canals; the third diversion sluice is for water diversion of 3 main canals; and the fourth diversion sluice is for water diversion of 5 main canals. Shenwu Main Canal has its independent inlet in the Yellow River.

\subsection{Drainage ditches}

The drainage system of Hetao Irrigation District is mostly corresponding to the irrigation canal system, at seven stages, respectively general main drainage ditch, main drainage ditch, sub-main drainage ditch, branch ditch, lateral drainage ditch, field ditch and sublateral ditch. At present, there is one general main drainage ditch, 12 main drainage ditches, 45 sub-main drainage ditches, 137 branch ditches and 11,275 lateral drainage ditches, field ditches and sublateral ditches. The general main drainage ditch is the main works of the drainage system in Hetao Irrigation District, with a total length of $206 \mathrm{~km}$. It is the only channel for the drainage, channel recession and flash flood drainage into the Yellow River. The entire general main drainage ditch works are composed of main drainage section, Wuliangsuhai Lake and outlet waste canal. Wuliangsuhai Lake is the drainage receive area of underground water, irrigation backwater and mountain flood in Hetao Irrigation District, and is also the production base of fish and reed. The water surface area of Wuliangsuhai Lake is $293 \mathrm{~km}^{2}$, with the reed-producing area of about $136 \mathrm{~km}^{2}$, the maximum average water depth is $1.8 \mathrm{~m}$ and the maximum water storage capacity is 550 million $\mathrm{m}^{3}$. In recent years, the annual water discharged into Wuliangsuhai Lake is more than 400 million $\mathrm{m}^{3}$. The outlet waste canal is the throat of drainage from Hetao Irrigation District to the Yellow River. It starts from Wumaoji at the south end of Wuliangsuhai Lake, passes through Baotou-Yinchuan Highway and Baotou-Lanzhou Railway and flows into the Yellow River at the mouth of Sanhuhe River, with a total length of $24.1 \mathrm{~km}$ and a controlled drainage area of 11.3756 million mu. Since its completion, it has subsided water of about 300 million $\mathrm{m} 3$ to the Yellow River every year, totaling 4.5752 billion $\mathrm{m} 3$ and with leached amount of salt of 9.44328 million tons. The Yellow River gate and outlet pump station are built on the waste canal $12 \mathrm{~km}$ downstream of Wumaoji sluice. The gate can be opened and closed according to the water level of Wuliangsuhai Lake and Yellow River and closed during the freeze-up period of the Yellow River to prevent Yellow River water flow backward.

The irrigation management in Hetao Irrigation District is performed in different patterns in different historical periods. From the Qin and Han Dynasties to the Tang Dynasty, the government-dominated management pattern was adopted under the background of garrison reclamation; 
in the Qing Dynasty and the Republic of China period, the non-governmental organization or private individualdominated management pattern was implemented, and the characteristics of official supervision and citizen management were increasingly perfected ${ }^{[3]}$; after 1949 , the state played a leading role in the construction and management of the main works in Hetao Irrigation District and water users played a major role in the management of field canal systems. The reasonable and effective management system with clear rights and responsibilities and in line with the background of the times is the critical guarantee for the sustainable development of Hetao Irrigation District.

\section{Benefits}

Since the establishment of Hetao Irrigation District, it has played a basic supporting role in agricultural production, ecological environment improvement, social stability and sustainability in Hetao Plain. Agricultural economic benefits: In the 2200 years since the establishment of Hetao Irrigation District, the construction and development of Yellow River diversion irrigation projects have directly promoted the development and prosperity of agriculture and social economy in Hetao Plain. The irrigated area was increased from $380,000 \mathrm{mu}$ in the flourishing period of Tang Dynasty to nearly 1 million mu in the late Qing Dynasty and 4 million mu in the Republic of China. At present, Hetao Irrigation District has an irrigated area of 10.2 million mu; the grain output was increased from 25,000 tons in the flourishing period of Tang Dynasty to 150,000 tons in the Republic of China and reached more than 3 million tons in 2018. The population was increased from 50,000 in the Han Dynasty to nearly 400,000 in the mid-20th century and reached about 1.5 million in 2018. Nowadays, Hetao Plain is an important granary in northern China. Ecological and environmental benefits: The construction and development of Yellow River diversion irrigation project system in Hetao area have promoted the transformation of Hetao Plain from nomadic civilization to agricultural civilization, and realized the harmonious development of agriculture and ecological environment in arid desert areas. Social, political and cultural benefits: Hetao Plain is an important military and geopolitical strategic area. From Qin and Han Dynasties to Sui and Tang Dynasties, the garrison reclamation in Hetao Plain maintained the national and social stability. Since the Ming and Qing Dynasties, the development of irrigation works in Hetao Plain supported by private funds and supervised by the government has played an irreplaceable role in regional economic development and social stability.

\section{Values}

Hetao Irrigation District has been playing its role in irrigation for more than 2200 years. With its outstanding scientific and technological, historical and cultural and ecological values, it has been a model of irrigation sustainability.

\subsection{Scientific and technological values}

Hetao Irrigation District is a model of water diversion irrigation projects in areas with hyper-concentration flows and gentle slopes in ancient times. It has achieved the comprehensive benefits of irrigation, drainage and water transportation with the scientific canal system planning, unique technical measures and the minimum engineering facilities at the lowest operation costs. Scientific and reasonable canal system planning: The most areas in Hetao Plain have the slope of 1/5000 1/8000. According to the characteristics of high in southwest and low in northeast of the Irrigation District, the diversion main canal inclines at 60 degrees with the main stream of the Yellow River, achieving the artesian diversion without dam in the plain with extremely small channel gradient. The scientific canal line planning has guaranteed the balance of scouring and silting of the channels. Although Hetao Irrigation District has undergone several large-scale engineering modifications, 13 main canals of more than 100 years have basically not been changed. Economically feasible channeling technologies: Hetao Plain was formed by flood impact of the Yellow River, with soft soil. By taking full advantage of the geological characteristics, the technology of small section excavation and large flow scouring was adopted when channeling to reduce the manpower and material inputs, and Elaeagnus angustifolia and Tamarix and other revetment plants were planted on the preset section, which not only ensures the design flow, but also guarantees the safety of water conveyance. Such technology was fully used in the design and construction of general main canal in 1961, which reduced the quantity of earth excavated by hand by 105 million $\mathrm{m} 3$ and greatly shortened the water supply time. Drainage project constructed according to local conditions: The water parent material of the Yellow River contains salt. Wujia River, Yellow River old riverway, is used as the drainage channel to drain water to Wuliangsuhai Lake, achieving annual leached amount of salt of about 1.2-1.8 million tons, which has greatly alleviated the salt accumulation in Hetao Irrigation District and effectively prevented the land salinization. The regulation in Wuliangsuhai Lake and discharge into the Yellow River have guaranteed the water quality safety of the Yellow River. Eco-environmental and locally sourced bank protection technology: "Pile washing out and fence building" is the traditional bank protection and shoal protection works still in use in Hetao Irrigation District. This technology has the advantages of resistance to freezing and thawing and silting and shoal stabilization in cold areas. These engineering types and traditional river engineering technologies, which are based on local conditions and use local materials, have undergone the technical improvement. The economical and environment-friendly materials are used, for example, the tamarix ramosissima fence was changed into bamboo fence, which is widely used in the new planning and design.

\subsection{Historical and cultural values}

Hetao Plain is located in arid and semi-arid area and the ecotone of agriculture and animal husbandry. The 
construction and development of Yellow River diversion irrigation project are of landmark significance to the development of agriculture, society politics, economy and culture in Hetao Plain. Together with the Great Wall, the irrigation works heritage in Hetao Irrigation District has witnessed the historical process of the conflict and integration of nomadic and agricultural civilization. The Yellow River diversion irrigation project has not only supported the regional stability and development, but also derived the irrigation agricultural culture with regional characteristics. For example, the contributions of folk forces to the construction and management of irrigation canals in the late Qing Dynasty made the Yellow River diversion irrigation project marked with the brands of culture and times, which was clearly reflected in the name of the canals. The Yellow River diversion irrigation area has currently become one of the typical representatives and labels of Bayan Nur local culture and is also an important embodiment of the historical and cultural values of Hetao Irrigation District heritage.

\subsection{Ecological and environmental values}

The irrigation works in Hetao Irrigation District have built the agroecological system and constructed the ecological barrier of northern China. The existence and operation of engineering system in Hetao Irrigation District are indispensable to the protection of the northwest-northnortheast China networks of shelterbelts, wind prevention and sand fixation, prevention and control of land desertification, containment of eastward invasion of Ulanbuh Desert, improvement of water ecological environment of Wuliangsuhai Lake and other lakes and wetlands and regional environmental landscape improvement. Its ecological value is becoming increasingly prominent and important.

\section{Summary}

Hetao irrigation area is located in the arid desert area and minority border area of Mongolian Plateau in northern China. Although the climate environment is bad and has been destroyed by wars in different dynasties, the Hetao irrigation area has not only become an important food production area in the past dynasties, but also greatly improved the local water conservancy and Yellow River irrigation. The ecological environment has become a rare oasis on the Inner Mongolia Plateau of the earth and an important ecological barrier with northern China, and its ecological value is becoming more and more prominent and important.

Although Hetao irrigation area is located in the arid desert plateau and minority border areas with an altitude of more than 1000 meters, the people of Hetao have been able to inherit the cause of irrigation and water conservancy from generation to generation for more than 2000 years. At present, the canal system irrigation in the ancient irrigation area has a large scale, and the grain production capacity has gradually increased from more than 300 million catties in the early days of the people's Republic of China, and stabilized at more than 6 billion jin.
It has become a well-known "granary on the block" in the whole country.

\section{Acknowledgments}

This work was supported by IWHR Research\& Development Support Program (JZ0145B572016).

\section{References}

1. Yuan Mingquan. Development of farmland and water conservancy in Hetao in Qing Dynasty [J]. Chinese agricultural history, 1986 (04): 16-24.

2. Ma Bo. Agricultural development in Hetao area in historical period $[\mathrm{J}]$. Ancient and modern agriculture, 1991 (01): 56-64.

3. Wang Jiange. Water conservancy system and social adaptation in Hetao area in the late Qing Dynasty [J]. Research on modern history, 2001 (06): 127-152. 